\title{
A pictorial key for the identification of beetle (Order: Coleoptera) and diversity study in selected area within Pelangai Forest Reserve, Negeri Sembilan, Malaysia
}

\author{
NURUL HUDDA ABDULLAH, IZZATI ADILAH AZMIR \\ School of Biology, Faculty of Applied Sciences, Universiti Teknologi MARA (UiTM) Negeri Sembilan. Kampus Kuala Pilah, Pekan Parit Tinggi, 72000 \\ Kuala Pilah, Negeri Sembilan, Malaysia. ‘email: izzati_adilah@uitm.edu.my
}

Manuscript received: 3 November 2020. Revision accepted: 22 January 2021

\begin{abstract}
Abdullah NH, Azmir IA. 2021. A pictorial key for the identification of beetle (Order: Coleoptera) and diversity study in selected area within Pelangai Forest Reserve, Negeri Sembilan, Malaysia. Biodiversitas 22: 947-955. Beetles or Coleoptera were largely distributed in Asia, especially in Malaysia. The beetle was important in the ecosystem as a decomposer, pollinator, and bioindicator of the habitat. However, the beetle could also be a potential pest to crops or plants that cause damage to many plantations. This study aimed to establish a key pictorial for beetle identification based on selected characteristics and to determine the beetle diversity, evenness, and genus similarity in Pelangai Preserved Forest, Negeri Sembilan at three different sites i.e., forest, open area, and the sub forested area. This study was carried out between February and March 2020. The Shannon Evenness Index (E) calculated species evenness and the Simpson's Index (D) assessed the diversity of beetles in this research. The results obtained were 67 individuals of beetles comprised of 7 families and 13 genera. The most found beetle was genus Apogonia sp. (16.4\%), followed by genus Epilachna sp. (14.9\%), and genus Adoretus sp. A (14.9\%) while the least found beetle was genus Blabephorus sp. (1.5\%). Site C or sub forested area had the highest species similarity $(\mathrm{E}=0.913)$, followed by Site B or open area $(\mathrm{E}=0.912)$ and Site A or forest area with the lowest species similarity $(E=0.908)$. This showed that the species in the sub forested area were evenly distributed compared to the forest and open area. As for diversity index, sub forest had the highest diversity $(D=0.860)$, followed by open area $(D=0.845)$ and forest area with the lowest diversity $(\mathrm{D}=0.188)$. In conclusion, the beetle from genus Rhyncophorus sp. was the most distinct among other beetles due to the presence of snout and visible head which make it easier to identify. Beetle from genus Apogonia sp. was most found in sub forested areas due to high vegetation and medium sun exposure. Sample collection can be increased in future study by using dung trap sample collection and longer sampling time.
\end{abstract}

Keywords: Beetle's identification, Coleoptera, diversity, key pictorial, Malaysia

\section{INTRODUCTION}

Pelangai Forest Reserve, with a total of 2,940.800ha land area was gazetted in 2001. This area has been listed as a permanent forest reserved by the government of Malaysia to ensure the forest will sustain its role in providing protective, productive, and amenity functions to society (Lim and Suksuwan 2007). Within the Pelangai Forest Reserve, situated a settlement area of Kampung Beting with a coverage area of $72.55 \mathrm{~km}^{2}$ (Jabatan Perhutanan Negeri Sembilan 2015). Kampung Beting is surrounded by preserved forests and comprised of unique ecosystems with diverse biodiversity of flora and fauna. The main plantation surrounding the area are oil palm trees thus it became a suitable habitat for a variety of organisms (Hasyimah et al. 2013; Zawawi et al. 2016; Noormi et al. 2018).

The current status of beetles in this area has been long overdue for assessment and beetles were found to be very different from other insects due to the presence of elytra or the front wings with different textures (Wen et al. 2020) The type of head, the shape of antennae, and tarsal numbers were the main keys to distinguish beetle from other insects
(Talarico et al. 2018). They were found widely all over the world with 350,000 species from 135 to 170 families (Betz et al. 2020) dominated by suborder Polyphaga. In Malaysia, about 170 species have been found in Peninsular Malaysia (Goh and Hashim 2019), where the most common beetles found were carabids, scarab beetles, weevils and long-horned beetles (Konishi et al. 2006). However, beetles were always misidentified as bugs and tend to falsely identify when sorted into family and genus as one might look similar to another. Thus, key pictorial was necessary for beetle identification. The data of beetle diversity in Kuala Pilah, in particular, was last updated in 2012 hence the assessment on current status of beetles was warranted. This is important to update their current diversity and composition status as it will allow the stakeholders to make proper arrangements for any future development planning. This research aimed to establish a key pictorial of the beetle samples collected at the study sites and to determine the beetle diversity and distribution in Pelangai Preserved Forest, Kuala Pilah. 


\section{MATERIALS AND METHODS}

\section{Sampling sites}

The sampling activities were conducted at three selected sites within Pelangai Forest Reserved. The selected sites were situated nearby Kampung Beting, Kuala Pilah, Negeri Sembilan, Malaysia where three different vegetations (Site A, Site B, and Site C) were chosen (Figure 1). Site A was a forested area, filled with high canopy trees where it received the least sunlight exposure onto the ground. The ground was covered with fallen branches, dried leaves, and bushes. The soil was dry and with low humidity. Site B was an open area located near a lake with a few short trees and covered by grasses. Site B was directly exposed to sunlight and was located near rubber plantations and palm trees. The soil was moist and humidity level is at minimal. Site $\mathrm{C}$ was sub forested area where it was surrounded by a lake, forest, few houses, and orchards. The area was covered with tall grasses and fruit trees. The area was partially exposed to sunlight. The soil was moist and the humidity level was the highest compared to Site A and Site B.

\section{Sampling methods}

The beetle samples were collected using light trap and sweep net from February to March 2020 in a total of 18 rounds of sampling. For light trap set up, a white sheet $(2 \mathrm{~m}$
$X 3 \mathrm{~m}$ ) was hanged vertically and tied using ropes on the tree at Site A, Site B and Site C. The lamp was placed above the white sheet and was left on for 12 hours from $7.00 \mathrm{pm}$ until $7.00 \mathrm{am}$. The collected samples were kept in containers separately according to the day of collection. Insect hunting using sweep net method was conducted twice a day during active period of the beetles (7.00 am and $5.00 \mathrm{pm}$ ) (White, 1983) with a duration of 2 to 3 hours per session. The beetle was scoured under the rocks, in the rotten trees, on plants, on grasses, and trees available at the respective locations.

\section{Beetle preservation and identification}

The collected beetles were placed in separate containers with $70 \%$ of ethanol solution and brought back to the laboratory for identification (Aruchunnan et al. 2016) according to family and genus. The identification process was done by observing their body parts such as head, pronotum, antennae, and elytra. The images of each body part were captured using Nikon D5300. The identification was done by referring to the Introduction to the Identification of Beetles (Coleoptera) (Choate 2003), Manual for Bornean Beetle Family Identification (Ching, 2003), and An Overview of Research on Beetle Diversity \& Taxonomy in Malaysia (Chung 2019).

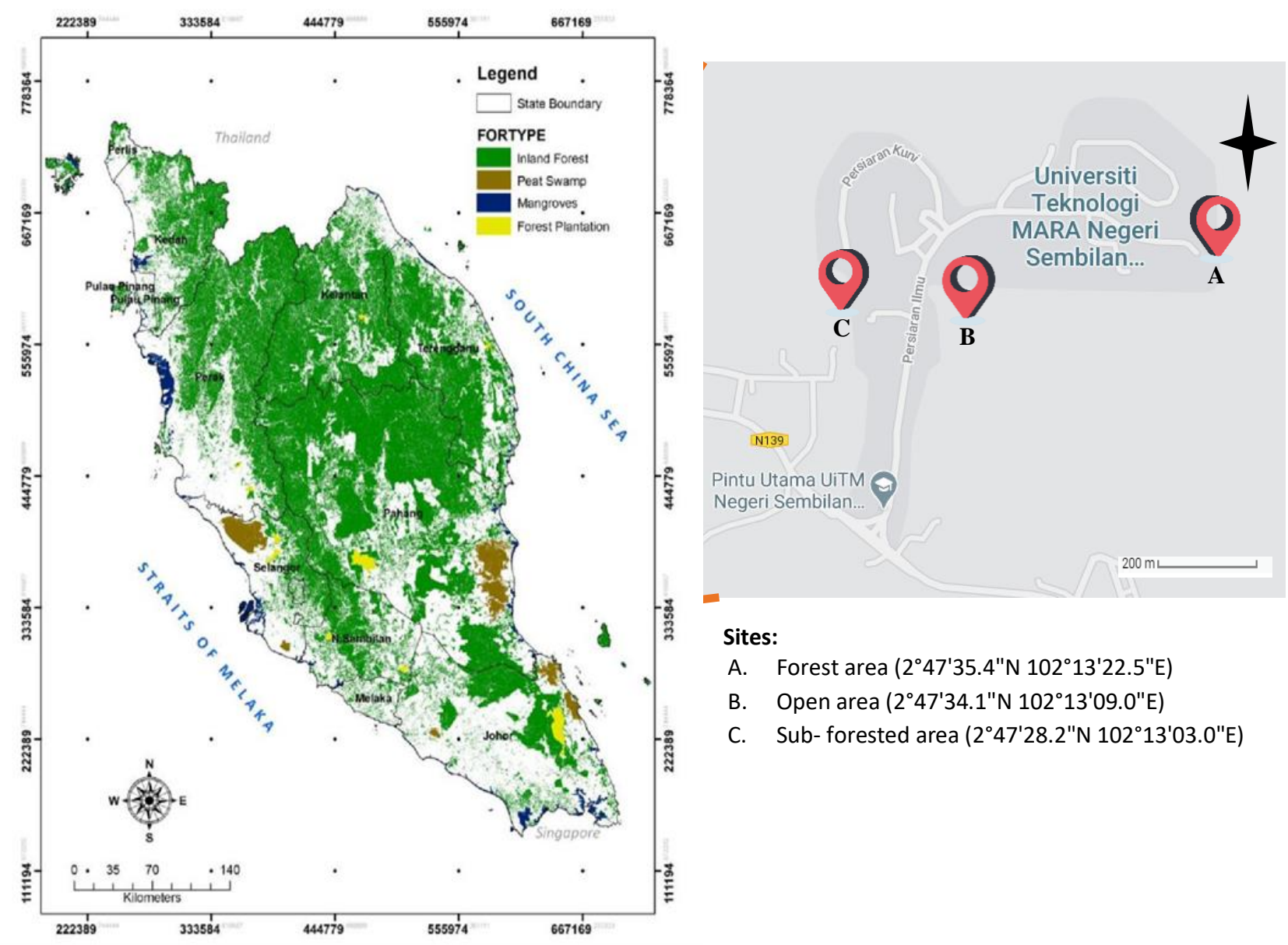

Figure 1. The three locations of sample collecting in Pelangai Forest Reserved nearby Kampung Beting, Negeri Sembilan, Malaysia (Omar et al. 2012; Google Map, Retrieved 1st June 2020) 


\section{Statistical analysis}

The data were analyzed by using Simpson's Diversity Index, Shannon Evenness Index, and Jaccard's Coefficient Index. High value of diversity index indicates diverse species found at a particular location compared to other locations (Bibi and Ali 2013). Simpson's Diversity Index was the number of species found over number of individuals in an area by the formula shown (Azmir et al. 2019).

$$
D=\frac{\sum n(n-1)}{N(N-1)}
$$

Based on this formula, D was diversity index, $\mathrm{n}$ was total number of individuals of particular species and $\mathrm{N}$ was total number of individuals. Shannon Evenness Index functioned in calculating the species evenness by calculating the diversity first, H'. High value of evenness index showed that number of species in the area was more evenly distributed (Bibi and Ali 2013).

$$
\begin{aligned}
& \mathrm{H}^{\prime}=\Sigma[(\mathrm{pi}) \mathrm{x} \ln (\mathrm{pi})] \\
& \mathrm{H}_{\max }=\ln (\mathrm{S}) \\
& E=\frac{H^{\prime}}{H \max }
\end{aligned}
$$

According to the formula, pi referred to the proportion number of species, $H^{\prime}$ was the diversity, $\mathrm{S}$ was number of species and E was evenness. Jaccard's Coefficient Index was used to indicate the similarity of species found between two sites. The higher the value, the more similar species found between the sites (Rahman et al. 2010).

$$
f(A, B)=\frac{|A \cap B|}{|A|+|B|-|A \cup B|}
$$

In coefficient index, $\mathrm{J}(\mathrm{A}, \mathrm{B})$ referred to the similarity index while $A \cap B$ was the number of species shared between two sets. A U B was the total number of species between two sets.

\section{RESULTS AND DISCUSSION}

A total of 67 individual beetles were collected from three sampling sites. From thorough observation, they were classified into 13 genera and 7 families as shown in the key pictorial below.

\section{Development of key pictorials for beetle identification in Pelangai Forest Reserve, Negeri Sembilan, Malaysia}

1 The coxa divides at first visible sternite at the abdomen. (Figure 2.A) Suborder Adephaga Legs not modified for swimming without visible fridges (Family Carabidae). (Figure 2.A) . Anatrichis sp.

1 ' The coxa does not divide at first sternite at the abdomen. (Figure 2B) Suborder Polyphaga, 2
2 Head with distinct beak or snout. (Figure 3.A) ...................................... Family Curculionidae, 3

2' Head lack of beak or snout. (Figure 3.B ...............4

3 Elongated body with striated elytra and larger body size up to $30 \mathrm{~mm}$. (Figure 4.A) .......... Rhyncophorus sp.

3' Elongated body with iridescent glitter-covered and size up to $12 \mathrm{~mm}$. (Figure 4.B) ................. Hypomeces $\mathrm{sp}$.

4 Antennae filiform longer than elytra (Family Cerambycidae). (Figure 5) ...................... Aeolesthes sp.

4' Antennae not fit the description................................. 5

5 Head clearly visible with bright body color (Family Coccinellidae). (Figure 6.A) ............ Epilachna sp.

5' Head longer and concealed from above. (Figure 6.B)

6 Elytra smooth, striated, and shiny with round compact body (Family Chrysomelidae). (Figure 7.A) .....

Chrysomelidae gen. sp.

6' Elytra grooved and striated. (Figure 7B) ...................... 7

7 Clavate segmented antennae with elongate body (Family Tenebrionidae). (Figure 8A) ....... Eleodes sp.

7' Antennae either lamellate or geniculate. (Figure 8B) Family Scarabaeidae, 8

8 Head with visible single horn. (Figure 9.A) ......... 9

8' Head without horn. (Figure 9.B) ..................... 10

9 Shiny elytra and brown rounder body with length between $25 \mathrm{~mm}$ to $30 \mathrm{~mm}$. (Figure $10 . \mathrm{A}$ )

Blabephorus sp.

9' Black groovy elytra and oval-like body with length between $30 \mathrm{~mm}$ to $50 \mathrm{~mm}$ (Figure 10.B) ..... Oryctes sp.

10 Flattened body, prominent shoulder with elytra slightly depressed. (Figure 11.A) ...................... Oxythrea sp.

10' Compact body without prominent shoulder. (Figure 11.B) ...11

11 Black compact body and grooved elytra without visible eyes. (Figure 12.A) ..................... Apogonia sp.

11 'Brown body with either hairy or smooth elytra and visible eyes (Figure 11.B and 12.B) .... Adoretus sp., 12

12 Compact elongate body with long tarsal claws. (Figure 13.A) ................................. Adoretus sp. A

12'Compact nearly round body with short tarsal claws. (Figure 13.B) ....................... Adoretus sp. B

The beetle was first recognized based on the hind coxae position, whether it was located on the first sternite or not. This key was important to distinguish between suborder Polyphaga and suborder Adephaga (Choate 2003). According to this study, only one family was under Adephaga, which was Carabidae and the other six families lie under suborder Polyphaga. The coxa divided at first visible sternite at the abdomen could be seen in Anatrichis sp. indicating beetle of suborder Adephaga. Next, the identification was done by observing the presence of a beak or snout. Head with snout beetle was from Family Curculionidae or commonly known as weevils (Devi et al. 
2017), where the sample from this study belong to genus Hypomeces and Rhyncophorus. Glitter dust on Hypomeces

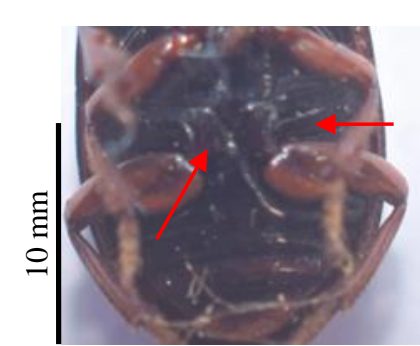

Figure 2.A

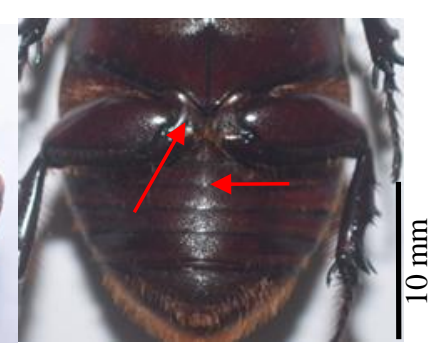

Figure 2.B

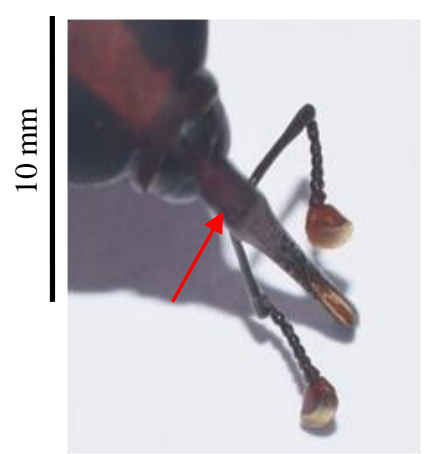

Figure 3.A

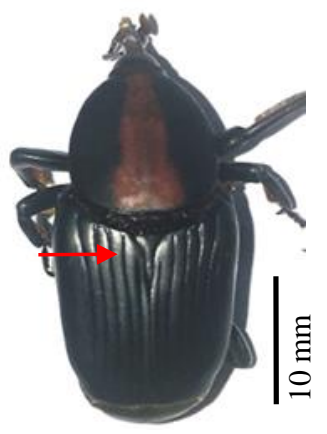

Figure 4.A

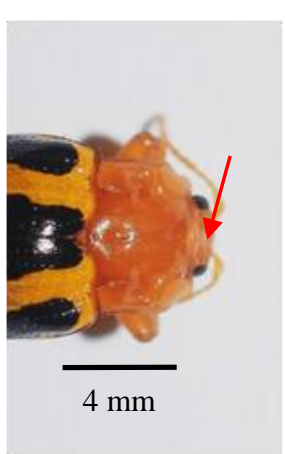

Figure 3.B

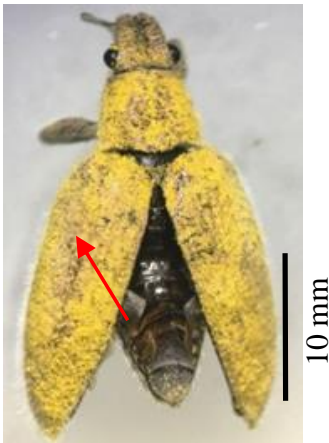

Figure 4.B

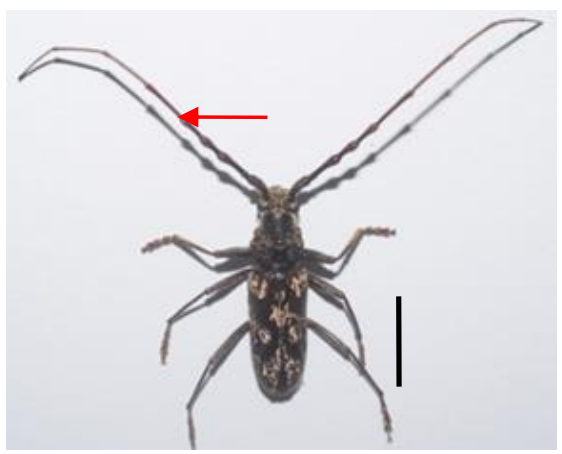

Figure 5

body also keys to differentiate between Rhyncophorus weevils that had striated elytra and larger body size.

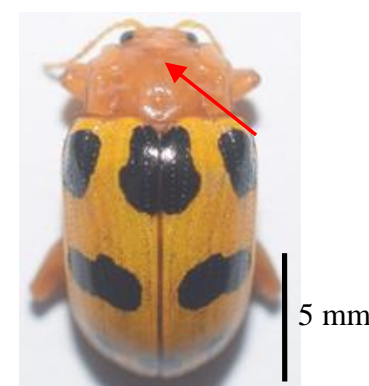

Figure 6.A

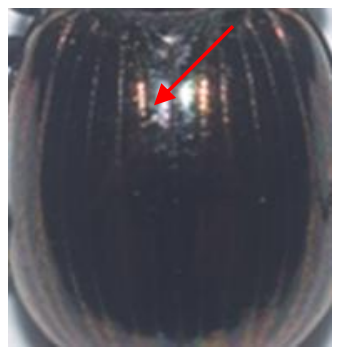

Figure 7.A

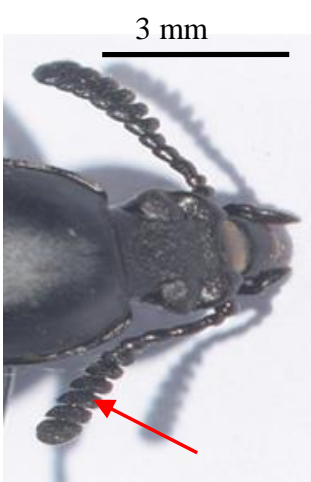

Figure 8.A

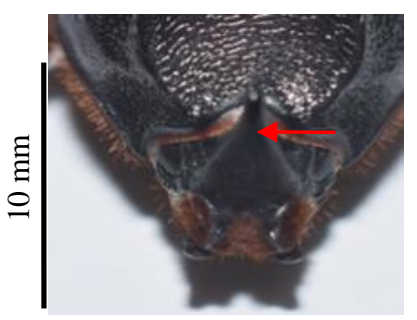

Figure 9.A

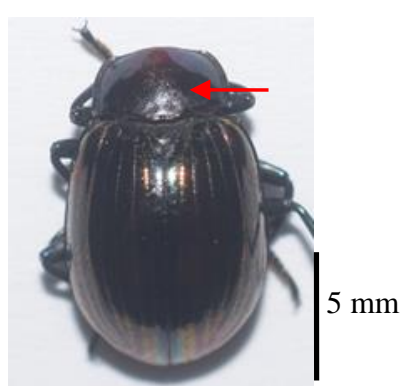

Figure 6.B

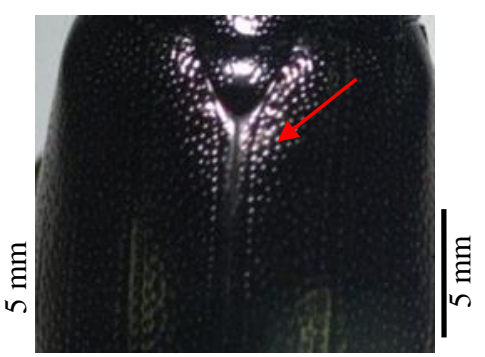

Figure 7.B

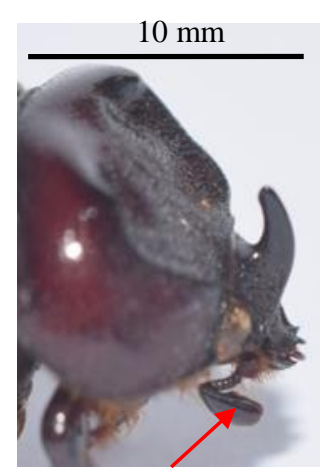

Figure 8.B

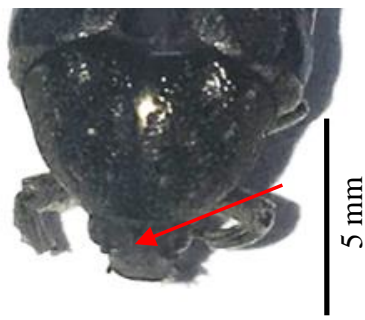

Figure 9.B 


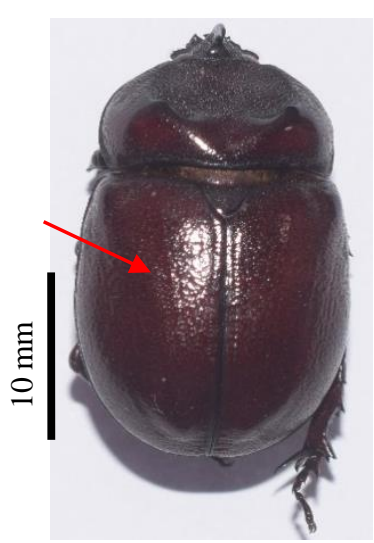

Figure 10.A

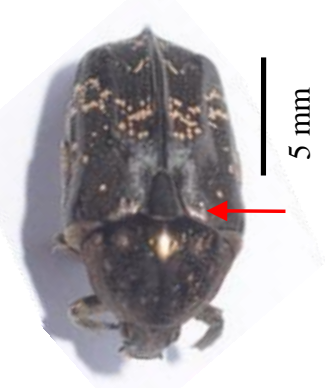

Figure 11.A

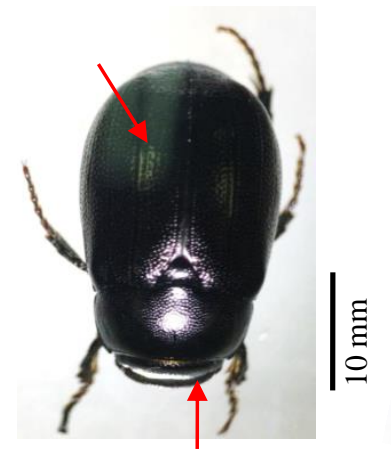

Figure 12.A

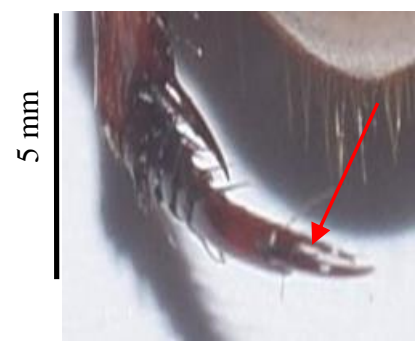

Figure 13.A

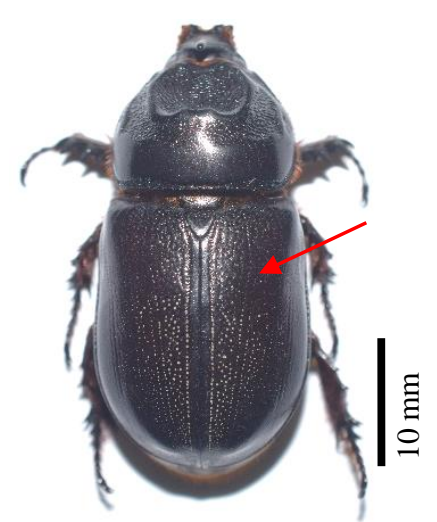

Figure 10.B

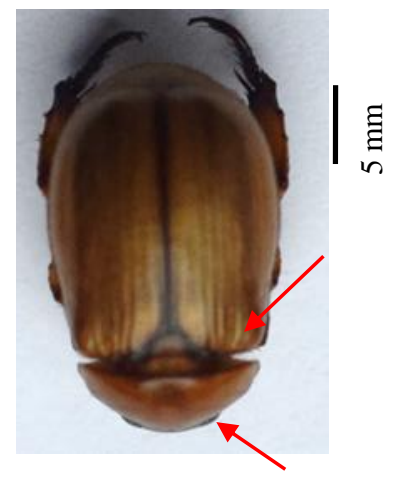

Figure 11.B

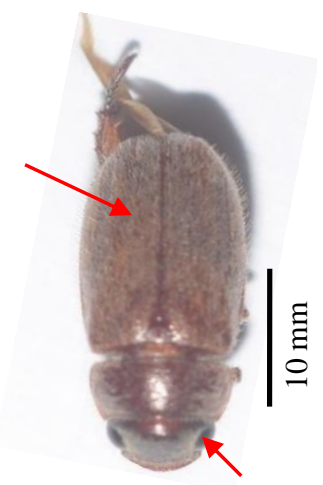

Figure 12.B

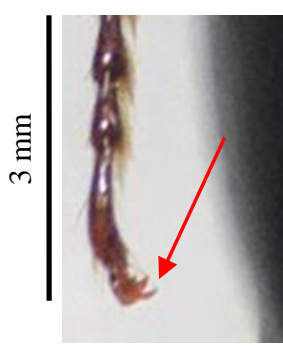

Figure 13.B
Another identification that distinguished beetle's family was the antennae. In this study, a few shapes of antennae had been recognized such as, filiform, geniculate, and clavate. The differences in elytra texture became a significant character to distinguish among sample caught and later enable to group them into distinct genus. The genus Oryctes had groovy elytra, Chrysomelidae had smooth elytra while genus Epilachna had shiny and patterned elytra. The length of the tarsal claws was used to differentiate the beetles. Short tarsal claws could be seen on Adoretus sp. B (Fig. 13B) while Adoretus sp. A (Fig. 13A) had long tarsal claws. Different body shapes, such as the prominent shoulder of Oxythrea gave a huge difference between genus of Family Scarabaeidae as shown in the key pictorial.

\section{The checklist of beetle between 2012 and 2020 in \\ Pelangai Forest Reserve, Negeri Sembilan, Malaysia}

The previous study of beetle in Pelangai Preserved Forest nearby Kampung Beting was conducted for the duration of three months applying sticky trap, window trap and yellow pan trap as the method of sampling. The total number of beetles collected was 361 individuals comprised of 23 genera and 6 families (Mohd 2012).

Variety of traps applied during the sampling session could be one of the main contributing factors to the high number of samples obtained (Sheikh et al. 2016). In 2020, the number of samples caught was found to be less than in 2012 due to the shorter time of sampling period and fewer methods of sampling were applied. Amount of sunlight and dry climates could also be led to a decrease in individual numbers sampled (Sultana 2018). Based on Table 1, there were four common families identified in both 2012 and 2020 namely Scarabaeidae, Cerambycidae, Chrysomelidae, and Carabidae.

These four common beetles were found despite the eight years sampling gap indicated an intact habitat in Pelangai Forest Reserved. The Scarabaeidae was simply found as they withstand various types of habitat including grasslands, farms, and forests because they fed on carrion, fungi, insects, or plants from plantations (Manjeri et al. 2013). Cerambycidae, Chrysomelidae, and Carabidae were still found in 2020 due to undisturbed forest area despite the potential of the area to undergo logging activity. As the height of the trees and canopy cover able to be maintained (Beiroz et al. 2019) thus favored them to inhabit these areas. An increase in plantations around the area also contributed to the presence of these three families because of the structural similarity of these plantations to the forest (Meng et al. 2013). Increase agriculture areas gave benefits to both Cerambycidae and Chrysomelidae as they fed on plants. The presence of deadwood contributed to the presence of Carabidae (Larsen et al. 2003). Both Cerambycidae and Scarabaeidae were found in 2020 due to thick sclerotization of their body integument, making them tolerated to dry and hot environments (Aldhafer et al. 2016).

Two families, Elateridae and Passalidae, were found in 2012 but were not sampled in 2020. Both families fed on decayed woods and favored cold and dark places (Perzada 
et al. 2018). The weather condition during the sampling period in the year 2020 was dry and hot hence these beetles could not be found at the sampling locations. Compared to the year of 2012, the sampling locations received a lot of rain and very humid (Mohd 2012). The dry and hot conditions in 2020 reduced the humidity and soil quality (Gómez-Cifuentes et al. 2019) where it was an important habitat preference for both Elateridae and Passalidae.

In 2020, new families were recorded namely Coccinellidae, Tenebrionidae and Curculionidae. The increase in agriculture activities has provided the three beetle families with food sources (Aldhafer et al. 2016). Coccinellidae fed on young plants while Tenebrionidae fed on decayed wood found in the forest (Cato et al. 2017). According to Yousefi et al. (2020), the Curculionidae or weevils were famous as plantations' pest hence explained their presence at the sampling sites which was surrounded by palm plantations and fruit farms.

\section{The occurrence of beetle at different vegetation in Pelangai Forest Reserve, Negeri Sembilan, Malaysia}

Based on this study, both open area (Site B) and sub forested area (Site $C$ ) were recorded with a higher number of genera (8 genera out of 13) compared to forest area (Site A) (5 genera) as shown in Table 2. Both open area and sub forested area received appropriate exposure to sunlight, covered by grasses and nearby to a water source (a lake). The most common genus found on each site was Apogonia sp., Chrysomelidae gen. sp., and Adoretus sp. This finding can be justified as they were all attracted to a habitat where herbaceous and shrubs plants are present (Teles et al. 2019).

According to this study, Hypomeces sp. was found more in sub forested area (Site C) compared to the open area (Site B) where tall grasses and bushes were present (Mashaly 2017). Scarab beetles or dung beetle species were found more in sub forested areas due to presence of few animals living in the forest such as squirrels and monkeys along with house waste or rubbish that attract these beetles (Nichols et al. 2008). Dung beetles also feed on fungi, carrion, or decayed matter (Bui et al. 2020). The beetles from family Cerambycidae and Tenebrionidae were found in the forest area (Site A) however absent in Site B and Site C. The Aeolesthes sp. or long-horned beetle was found in Site A as they favored high trees (Jukes et al. 2002) while Eleodes sp. preferred area filled with decayed tree and rotting wood (Site A), compared to the open area (Site B) and sub forested area (Ste C) (Darya et al. 2016). Since the open area (Site B) was located near a lake together with grassy land and a few flowering plants, it had attracted Epilachna sp. that fed on plants and leaves (Satheesha et al. 2018).

The genus Oryctes and Rhyncophorus were known as pest beetles that damaged plantations (Ramli et al. 2019). While Oxythrea sp. or flower chafer beetles mostly found in Site B and Site C, as they were attracted to flowering plant presence on each site (Ek-Amnuay 2008). Blabephorus sp. was only found on Site $\mathrm{C}$ where humidity level was the highest and broadleaf trees were present (Sultana 2018). Apogonia sp. or also known as plantation pest (Parisi et al. 2020) was found abundant in Site C compared to rest of sampling locations as the area filled with fruit trees.

Table 1. Checklist beetle's family between 2012 data and 2020 in Pelangai Preserved Forest, Kampung Beting, Negeri Sembilan, Malaysia

\begin{tabular}{|c|c|c|c|}
\hline Family & Genus & $\begin{array}{c}2012 \\
\text { (Mohd } \\
\text { 2012) } \\
\end{array}$ & $\begin{array}{c}2020 \\
\text { (Present } \\
\text { study) }\end{array}$ \\
\hline \multirow[t]{9}{*}{ Scarabaeidae } & Catharsius sp. & + & - \\
\hline & Chalcosoma sp. & + & - \\
\hline & Onthophagus sp. & + & + \\
\hline & Oxythrea sp. & + & + \\
\hline & Oryctes sp. & + & + \\
\hline & Apogonia sp. & + & + \\
\hline & Adoretus sp. & + & + \\
\hline & Blabephorus sp. & + & + \\
\hline & Maladera sp. & + & - \\
\hline \multirow[t]{2}{*}{ Cerambycidae } & Aeolesthes sp. & + & + \\
\hline & Hoplocerambyx sp. & + & - \\
\hline \multirow[t]{4}{*}{ Chrysomelidae } & Lilioceris sp. & + & - \\
\hline & Lema sp. & + & - \\
\hline & Brontispa sp. & + & - \\
\hline & Chrysomelidae gen. sp. & - & + \\
\hline \multirow[t]{3}{*}{ Carabidae } & Anatrichis sp. & + & + \\
\hline & Aephnidius sp. & + & - \\
\hline & Trigonotoma sp. & + & - \\
\hline \multirow[t]{3}{*}{ Elateridae } & Sternocampsus sp. & + & - \\
\hline & Alaus sp. & + & - \\
\hline & Chiasosnios sp. & + & - \\
\hline \multirow[t]{3}{*}{ Passalidae } & Acerains sp. & + & - \\
\hline & Ophrygonius sp. & + & - \\
\hline & Leptaulax sp. & + & - \\
\hline Coccinellidae & Epilachna sp. & - & + \\
\hline Tenebrionidae & Eleodes sp. & - & + \\
\hline \multirow[t]{2}{*}{ Curculionidae } & Hypomeces sp. & - & + \\
\hline & Rhyncophorus sp. & & + \\
\hline Total genus & & 23 & 13 \\
\hline
\end{tabular}

Note: +: Present; -: absent

Table 2. The occurrence of beetles based on three collecting sites in Pelangai Preserved Forest, Kampung Beting, Negeri Sembilan, Malaysia

\begin{tabular}{lllll}
\hline Family & Genus & $\begin{array}{l}\text { Site } \\
\text { A }\end{array}$ & $\begin{array}{l}\text { Site } \\
\text { B }\end{array}$ & $\begin{array}{l}\text { Site } \\
\text { C }\end{array}$ \\
\hline Cerambycidae & Aeolesthes sp. & 3 & 0 & 0 \\
Chrysomelidae & Chrysomelidae gen. sp. & 2 & 2 & 1 \\
Coccinellidae & Epilachna sp. & 0 & 10 & 0 \\
Curculionidae & Hypomeces sp. & 0 & 2 & 4 \\
& Rhyncophorus sp. & 0 & 3 & 0 \\
Scarabaeidae & Adoretus sp.A & 1 & 4 & 5 \\
& Adoretus sp.B & 0 & 0 & 5 \\
& Apogonia sp. & 1 & 3 & 7 \\
& Blabephorus sp. & 0 & 0 & 1 \\
& Oryctes sp. & 0 & 3 & 0 \\
Tenebrionidae & Oxythyrea sp. & 0 & 2 & 2 \\
Carabidae & Eleodes sp. & 4 & 0 & 0 \\
Total Genus & Anatrichis sp. & 0 & 0 & 2 \\
\hline & & 5 & 8 & 8 \\
\hline
\end{tabular}




\section{The diversity and distribution of beetles in Pelangai Forest Reserve, Negeri Sembilan, Malaysia}

Forest area (Site A) was recorded with $\mathrm{D}=0.188$, open area (Site B) with $\mathrm{D}=0.845$ and sub forest area (Site C) with $\mathrm{D}=0.860$, respectively. The high value showed in sub forest proved that it has the highest diversity followed by open area and forest area. In the meantime, the evenness index $(\mathrm{E})$ for forest area was $\mathrm{E}=0.908$, open area with $\mathrm{E}=$ 0.912 and sub forested area recorded with $\mathrm{E}=0.913$. The highest species evenness index was recorded in sub forest while forest area had the lowest evenness index. This showed that the beetles found in sub forested areas were evenly distributed among species types compared to the other sampling sites. The diversity and evenness data were shown in Table 3.

Highest diversity and evenness distribution values recorded in sub forested areas (Site C) were contributed by the presence of orchards, forest, and housing areas that were favored as habitat by various beetle species thus led to high species diversity found (Chung 2019). According to Aldhafer et al. (2016) variety in vegetation types such as tall grasses in sub forested areas (Site C), would lead to higher resource availability for beetles to inhabit the area.

Site A or forest area was recorded with the lowest diversity which could be influenced by the quality of soil and temperature (Qodri et al. 2016). Lack of water resources at Site A has caused the soil to be drier compared to the open area (Site B) and sub forested area (Site C) that was located next to a lake, thus reducing the soil quality). Eleodes sp. and Aeolesthes sp. were only found in the forest due to their thick sclerotization of body integument that allowed them to tolerate drier and hotter conditions (Riley and Browne 2011). The Cerambycidae, Scarabaeidae, Tenebrionidae, and Chrysomelidae preferred the forest area where tall trees were abundant and deadwood volumes (Stereńczak et al. 2020). The beetle's diversity was too low in Site A even though it is within the range of Simpson Index, D value between zero to one. Low in $\mathrm{D}$ value concluded that there might be more species and number of beetles that were not fully recovered in the area thus, further research should be done (Bird et al. 2017).

Based on Jaccard's Coefficient (Figure 3), genus similarity among beetles at three sampling sites was recorded as the highest in similarity at the open area (Site B) and sub forest area (Site $\mathrm{C})(\mathrm{J}=0.45)$. The similarity of beetle genus between forest (Site A) and open area (Site B) was recorded with $\mathbf{J}=0.30$ similar to forest area (Site A) and sub forested area (Site $\mathrm{C})(\mathrm{J}=0.30)$.

Table 3. Diversity and distribution index of beetles collected in Pelangai Preserved Forest, Kampung Beting, Negeri Sembilan, Malaysia

\begin{tabular}{lcc}
\hline \multicolumn{1}{c}{ Sites } & Evenness Index $(\mathbf{E})$ & Simpson Index $(D)$ \\
\hline Site A & 0.908 & 0.188 \\
Site B & 0.912 & 0.845 \\
Site C & 0.913 & 0.860 \\
\hline
\end{tabular}

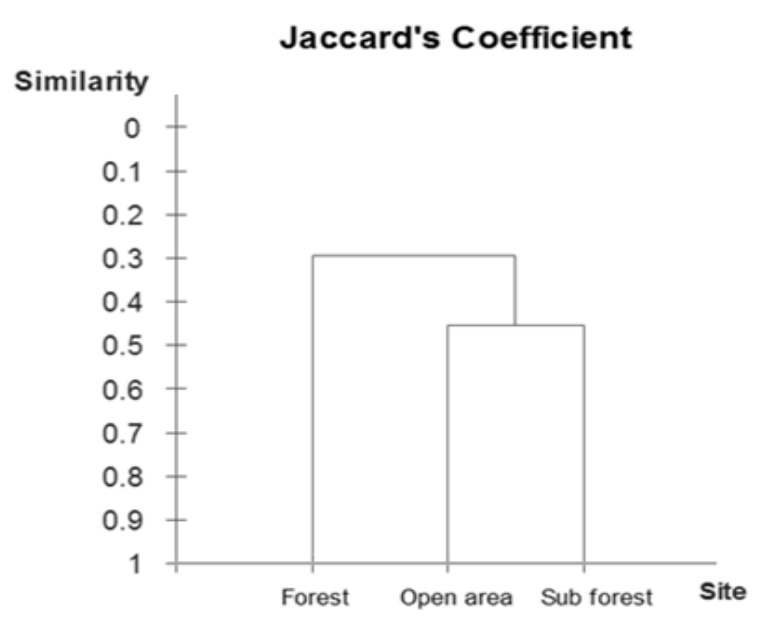

Figure 3. A dendrogram of beetle genus similarity between three sampling sites in Pelangai Preserved Forest, Kampung Beting, Negeri Sembilan, Malaysia

Both open area and sub forested area had the highest similarity coefficient with 5 genera of beetles were found which were Chrysomelidae gen. sp., Hypomeces sp., Adoretus sp. A, Apogonia sp. and Oxythyrea sp. Open area and sub forested area had several similarities involving humidity, soil quality, vegetation, and beetle's food resources (Egerer et al. 2017). Both open areas and sub forested had tall and grassy lands that allowed the beetles to inhabit. These two sites received water supply from the nearby lake making the soil moisturized and became favorable to the beetles (Riley and Browne 2011). The low humidity and moist soil condition favored most of the beetle's family (Betz et al. 2020). As for vegetation, open area and sub forested area located near palm plantations, orchards, and farms. This varied vegetation increased the food resource of beetles.

In conclusion, the successful construction of key pictorial has helped identify 13 genera of beetles in Pelangai Forest Reserve. The beetle identification was based on five major characteristics which were the type of antennae, body shape, body length, elytra, and tarsal separating them into family and genus level. The key pictorial will be applicable to identify 13 genera of beetle not only in Pelangai Forest Reserve but also around the world. The study on the diversity, evenness, and similarity of beetle occurrence in 2020 had been identified and updated with profound findings or three new families of Coccinellidae, Tenebrionidae and Curculionidae were found in 2020 but not in 2012. The sub forested area (Site C) was the best habitat for beetle based on the highest evenness distribution and highest species diversity index followed by open area (Site B) and forest area (Site A) as the least favored habitat preference. Air humidity, sun exposure and type of vegetation hugely affect the beetle's distribution in the respective locations. 


\section{ACKNOWLEDGEMENTS}

This research paper was made with the help from Universiti Teknologi MARA Kuala Pilah and Jabatan Perhutanan Negeri Sembilan.

\section{REFERENCES}

Aldhafer HM, Abdel-Dayem MS, Aldryhim YN, Fadl HH, El-Torkey A M, Elgharbawy AA, Setyaningrum H. 2016. Diversity and composition of ground-dwelling beetle assemblages (Insecta: Coleoptera) in Rawdhat Khorim National Park, Kingdom of Saudi Arabia. J Arid Environ 127: 187-191.

Azmir IA, Amin S, Esa Y, Yasin ISM, Ara R. 2019. A snapshot study on larval fish diversity in selected mangrove areas of Peninsular Malaysia, Malaysia. J Acad 7 (2): 112-123.

Beiroz W, Vieira L, Louzada J. 2019. Ecological similarity promotes coexistence between taxonomically related dung beetles species. Acta Oecol 96: 29-34.

Betz O, Srisuka W, Puthz V. 2020. Elevational gradients of species richness, community structure, and niche occupation of tropical rove beetles (Coleoptera: Staphylinidae: Steninae) across Mountain Slopes in Northern Thailand. Evol Ecol 34 (2): 193-216.

Bibi F, Ali Z. 2013. Measurement of diversity indices of avian communities at Taunsa Barrage Wildlife Sanctuary, Pakistan. Journa of Animal and Plant Sciences 23 (2): 469-474.

Bird TLF, Dorman M, Ramot A, Bouskila A, Bar Kutiel P, Groner E. 2017. Shrub encroachment effects on habitat heterogeneity and beetle diversity in a Mediterranean Coastal Dune system. Land Degrad Dev 28 (8): 2553-2562.

Bui VB, Ziegler T, Bonkowski M. 2020. Morphological traits reflect dung beetle response to land use changes in tropical karst ecosystems of Vietnam. Ecol Indic 108: 105697

Cato AJ, Elliott B, Nayak MK, Phillips TW. 2017. Geographic variation in phosphine resistance among North American populations of the red flour beetle (Coleoptera: Tenebrionidae). J Econ Entomol 110 (3): $1359-1365$

Choate PM. 2003. Introduction to the identification of beetles (Coleoptera). Retrieved June 1, 2020, from www.entnemdpt.ufl.edu/choate/beetlesla.pdf

Chung AYC. 2019. An overview of research on beetle diversity and taxonomy in Malaysia. Seminar on the Status of Biological Diversity in Malaysia, FRIM, Kepong. 28-30.

Costa MS, Silva RJ, Paulino-Neto HF, Pereira MJ. 2017. Beetle pollination and flowering rhythm of Annona coriacea mart (Annonaceae) in Brazilian Cerrado: Behavioral features of its principal pollinators. PLoS One 12 (2): e0171092. DOI: 10.1371/journal.pone.0171092

Darya H, Azura AN, Lau WH, Izfa RH, Maa A, Ahmed AM. 2016. Distribution of Darkling beetles (Tenebrionidae) in Malaysia. J Entomol Zool 4 (5): 1113-1117.

Egerer MH, Bichier P, Philpott SM. 2017. Landscape and local habitat correlate of lady beetle abundance and species richness in urban agriculture. Ann Entomol Soc Am 110 (1): 97-103.

Ek-Amnuay P. 2008. Beetles of Thailand (Second Edition). Siam InsectZoo and Museum, Thailand.

Goh TG, Hashim R. 2019. Conservation of Dung beetles (Scarabaeidae: Scarabaeinae) in Peninsular Malaysia. Journal of Wildlife and Parks 34: 81-93.

Gómez-Cifuentes A, Gómez VCG, Moreno CE, Zurita GA. 2019. Tree retention in cattle ranching systems partially preserves Dung beetle diversity and functional groups in the semideciduous Atlantic Forest: The role of microclimate and soil conditions. Basic Appl Ecol 34: 6474

Google Map. 2020. UiTM Kuala Pilah Map. Retrieved June 1, 2020 www.google.com/maps/place/Pintu+Utama+UiTM+Negeri+Sembilan ,+Kuala+Pilah+Campus+ (Beting) $/$

Jabatan Perhutanan Negeri Sembilan. 2015. Keluasan hutan simpanan kekal (HSK) Negeri Sembilan. Retrieved June 1, 2020 http://forestry.ns.gov.my/index.php/my/sumber/maklumat-sumberhutan/keluasan-hutan-simpanan-kekal-hsk-negeri-sembilan
Jukes M R, Ferris R, Peace AJ. 2002. The influence of stand structure and composition on diversity of canopy Coleoptera in coniferous plantations in Britain For Ecol Manag 163 (1-3): 27-41.

Konishi S, Tani M, Kosugi Y, Takanashi S, Sahat MM, Nik AR, Niiyama K, Okuda T. 2006. Characteristics of spatial distribution of throughfall in a lowland tropical rainforest, Peninsular Malaysia. For Ecol Manag 224 (1-2): 19-25.

Larsen KJ, Work TT, Purrington FF. 2003. Habitat use patterns by ground beetles (Coleoptera: Carabidae) of Northeastern Iowa. Pedobiologia 47 (3): 288-299.

Lim T, Suksuwan S. 2007. An assessment of the status of permanent reserved forests in Peninsular Malaysia, 2001-2005. WWF- Malaysia Discussion Paper. Retrieved October 24, 2020, from https://www.academia.edu/4362532/An_Assessment_of_the_Status_o f_Permanent_Reserved_Forests_in_Peninsular_Malaysia_2001_2005.

Manjeri G, Muhamad R, Faridah QZ, Tan SG. 2013. Morphometric analysis of Oryctes rhinoceros (L.) (Coleoptera: Scarabaeidae) from oil palm plantations. Coleopt Bull 67 (2): 194-200.

Mashaly AM. 2017. Carrion beetles succession in three different habitats in Riyadh, Saudi Arabia. Saudi J Biol Sci 24 (2): 430-435.

Meng LZ, Martin K, Weigel A, Yang XD. 2013. Tree diversity mediates the distribution of Longhorn beetles (Coleoptera: Cerambycidae) in a changing tropical landscape (Southern Yunnan, Sw China). PLoS One 8 (9): e75481. DOI: 10.1371/journal.pone.0075481

Mohd TFT. 2012. Preliminary Study on Beetle Diversity at Forest Reserved UiTM Kuala Pilah. Universiti Teknologi MARA (UiTM), Kuala Pilah.

Nichols E, Spector S, Louzada J, Larsen T, Amezquita S, Favila ME. 2008. ecological functions and ecosystem services provided by Scarabaeinae Dung beetles. Biol Conserv 141 (6): 1461-1474.

Noormi R, Shamsuddin RA, Shukri AMA, Sahabudin NSL, Rahman RA, Adawiyah R, Shukri AMA, Sahabudin NSL, Rahman RA, Mutalib SNA. 2018. Species composition and biodiversity of organisms in University of Technology MARA ( UiTM ) Kuala Pilah, Negeri Sembilan, Malaysia. J Acad 6 (2): 18-27.

Hasyimah RN, Syakira MH, Mohd Syahril MZ, Samat A, Iwana I. 2013. Water quality, diversity and distribution of freshwater fishes in Negeri Sembilan. J Acad 3: 10-19.

Parisi F, Frate L, Lombardi F, Tognetti R, Campanaro A, Biscaccianti A B, Marchetti M. 2020. Diversity patterns of Coleoptera and saproxylic communities in unmanaged forests of Mediterranean Mountains. Ecol Indic 110: 105873 .

Perzada AA, Depar RA, Soomro AA, Mastoi SM, Chandio MA, Mangi S, Magsi FH, Khushk MA, Kumbhar, S. 2018. Biodiversity of click beetles (Elateridae) of Tandojam. J Entomol Zool 6 (2): 2808-2814

Qodri A, Raffiudin R, Noerdjito WA. 2016. Diversity and abundance of Carabidae and Staphylinidae (Insecta: Coleoptera) in four montane habitat types on Mt. Bawakaraeng, South Sulawesi. Hayati 23 (1): 2228

Rahman M, Hassan MR, Buyya R. 2010. Jaccard index-based availability prediction in Enterprise Grids. Procedia Comput Sci 1 (1): 2707-2716.

Ramli NH, Din M, Rahim NAA, Halim WNMWA, Muhaimin A, Yaakop S. 2019. A preliminary study on the diversity and abundance of Onthophagus species (Coleoptera: Scarabaeidae) in an oil palm plantation, Peninsular Malaysia in relation to carbon dioxide and soil organic matter. Pertanika J Trop Agric Sci 42 (1): 405-419.

Riley KN, Browne RA. 2011. Changes in ground beetle diversity and community composition in age structured forests (Coleoptera, Carabidae). Zookeys 147: 601-621.

Devi SR, Thomas, A, Rebijith KB, Ramamurthy VV. 2017. Biology, morphology and molecular characterization of Sitophilus oryzae and S. zeamais (Coleoptera: Curculionidae). J Stored Prod Res 73: 135141.

Satheesha DNA, Vrushali MM, Jayaraj FC, Sreenivasa G. 2018. Preliminary study on composition and diversity of beetles (OrderColeoptera) in and around Davangere University Campus, Davangere, Karnataka. J Entomol Zool 6 (4): 1751-1758.

Sheikh AH, Bunkar K, Thomas M, Bhandari R, Bunkar K. 2016. Light trap and insect sampling: An Overview. Int J Curr Res 8 (11): 4086840873.

Stereńczak K, Mielcarek M, Kamińska A, Kraszewski B, Piasecka Ż Miścicki S, Heurich M. 2020. Influence of selected habitat and stand factors on Bark beetle Ips typographus (L.) Outbreak in the Białowieża Forest. For Ecol Manag 459: 117826. 
Sultana FDSAR. 2018. Incidence of Darkling beetles (Coleoptera: Tenebrionidae) from Lower Sindh Tando Jam Hyderabad. J Entomol Zool6 (2): 2560-2562.

Talarico F, Cavaliere F, Mazzei A, Brandmayr P. 2018. Morphometry and eye morphology of three scaritine ground beetles relate to habitat demands and behavioural traits (Coleoptera, Carabidae, Scaritinae). Zool Anz 277: 190-196.

Teles TS, Ribeiro DB, Raizer J, Linzmeier AM. 2019. Richness of Chrysomelidae (Coleoptera) depends on the area and habitat structure in semideciduous forest remnants. Iheringia Sér Zool 109

Wen C, Ma T, Deng Y, Liu, C, Liang S, Wen J, Wang C, Wen X. 2020. Morphological and optical features of the apposition compound eye of Monochamus alternatus hope (Coleoptera: Cerambycidae). Micron 128: 102769 .

White RE. 1983. A field guide to beetle in North America. Houghton Mifflin Company, Boston.

Yousefi M, Rafie ASM, Aziz SA, Azrad S, Razak ABA. 2020. Introduction of current pollination techniques and factors affecting pollination effectiveness by Elaeidobius kamerunicus in oil palm plantations on regional and global scale: A Review. S Afr J Bot 132: 171-179.

Zawawi AZM, Azmir I, Ishak N, Rahim NA, Sharif A. 2016. Study on population size of Hirundo tahitica in UiTM Negeri Sembilan, Kuala Pilah Campus. Regional Conference on Science, Technology and Social Sciences (RCSTSS 2014) Science and Technology, 565-571. 